\title{
ПОРТОКАВАЛЬНЕ ШУНТУВАННЯ ЯК СПОСІБ УСУНЕННЯ ПОРТАЛЬНОЇ ГIПЕРТЕНЗІЇ У ХВОРИХ НА ЦИРОЗ ПЕЧІНКИ
}

\author{
О. Ф. Дзигал, Ю. В. Грубник, І. В. Савицький \\ Одеський національний медичний університет \\ PORTOCAVAL SHUNTING AS A MODE OF PORTAL HYPERTENSION REMOVAL
IN PATIENTS WITH LIVER CIRRHOSIS
}

\author{
O. F. Dzygal, Yu. V. Grubnik, I. V. Savitskiy \\ Odessa National Medical University
}

\begin{abstract}
Рeфpepat
У 98 хворих з приводу цирозу печінки (ЦП) та портальної гіпертензії (ПГ) виконано мініінвазивну операцію портокавального шунтування (ПКШ). Для селективної декомпресії системи ворітної вени (ВВ) формували дистальний спленоренальний анастомоз, для ії̈ парціальної декомпресії - портокавальні анастомози. Наведені показання та протипоказання до виконання операції ПкШ. Тривалість спостереження безпосередньо після операції $3-6$ міс, у віддаленому періоді $-4-5$ років. Дані клінічного спостереження свідчать про доцільність виконання ПКШ у хворих на ЦП, покращення клінічного стану хворих, декомпресію системи ВВ, зменшення тяжкості енцефалопатії, частоти ускладнень. Селективне і парціальне ПКШ з метою корекції ПГ при ЦП є ефективним засобом лікування основного захворювання, забезпечує попередження стравохідно-шлункової кровотечі у віддаленому періоді спостереження, виживання пацієнтів за компенсованої або субкомпенсованої функції печінки.

Ключові слова: цироз печінки; селективне і парціальне портокавальне шунтування; декомпресія системи ворітної вени.

Abstract

We performed mini-invasive surgery of portocaval shunting (PCS) in 98 patients with liver cirrhosis (LC) and portal hypertension (PH). We formed distal splenorenal anastomosis in order to perform selective decompression of vena cava and portocaval anastomoses - for its partial decompression. Indications and contraindications for the PCS surgery are given. We observed the patients directly after the surgery during 3-6 months, the long-term follow-up lasted for 4-5 years. Clinical observation data prove the advantages of PCS in patients with LC. The surgery resulted in clinical improvement, vena cava system decompression, decrease of the encephalopathy and of the rate of complications. Selective and partial PCS for PH correction is an effective treatment of LC. It prevents gastroesophageal bleeding during long-term follow-up, improves patient survival when liver function is compensated or subcompensated.

Keywords: liver cirrhosis; selective and partial portocaval shunting; vena cava system decompression.
\end{abstract}

Хронічні дифузні захворювання печінки, ЦП, провідним клінічним симптомом яких $є$ ПГ, $є$ актуальною проблемою абдомінальної хірургії, що має соціальну й економічну значущість [1 - 3].

Найбільш загрозливим та найчастішим ускладненням ПГ є кровотеча з варикозно-змінених вен стравоходу і шлунка, що зумовлює значну летальність хворих [3]. Клінічно обгрунтованим способом корекції ПГ є селективна та/або парціальна декомпресія в системі ВВ, ефективність якої визначається особливостями клінічного стану пацієнтів після операції. Одним з таких способів хірургічного лікування є ПКШ - хірургічна гемодинамічна корекція ПГ, що передбачає створення штучного каналу між порожнистою веною та ВВ для відтоку венозної кро- ві в обхід печінки [4]. При виборі такого методу хірургічного лікування хворих на ЦП ми виходили з даних про низьку частоту тромбозу судинних сполучень, незначну післяопераційну летальність, частоту післяопераційних ускладнень та формування «постшунтової енцефалопаTiii» $[5-7]$.

Обгрунтованість вибору методу хірургічної корекції ПГ обговорюється, проте, маючи певний досвід хірургічного лікування таких хворих, ми досягли позитивних результатів.

Очевидно, у таких пацієнтів слід використовувати спеціальні хірургічні технології, а також індивідуальний підхід, на підставі якого розробити індивідуальну тактику лікування. Проведений ретроспективний аналіз ефективності лікування хво- рих з приводу ЦП з ПГ, яким виконане ПКШ

Мета дослідження: визначення ефективності хірургічної корекції ПГ у хворих на ЦП при виконанні операції ПКш.

\section{МАТЕРІАЛИ I МЕТОДИ ДОСЛІДЖЕННЯ}

Протягом 7 років в клініці лікували 262 хворих $з$ приводу ЦП віком від 36 до 69 років. Жінок було 164 (62,6\%), чоловіків - 98 (37,4\%). Віком старше 40 років були 67 (25,6\%) пацієнтів, старше 50 років - 97 (37\%), старше 60 років - 56 (21,4\%). Діагноз ЦП встановлювали на підставі аналізу результатів клінічного обстеження хворих, біохімічного аналізу крові, ультразвукового дослідження (УЗД) органів гепатопанкреатодуоденальної зони, комп'ютерної 
томографії, ендоскопічної ретроградної панкреатохолангіографії тощо.

ПКШ виконане у $98(37,4 \%)$ пацієнтів, в тому числі чоловіків - 59 (60,2\%), жінок - 39 (39,8\%), віком від 42 до 67 років, у середньому (54,7 \pm 9,6) року. За класифікацією ChildPugh [8], ЦП у стадії компенсації (I стадія) відзначений у 31 (31,6\%) хворого, субкомпенсації (II стадія) - у 50 (51\%), декомпенсації (III стадія) у $17(17,4 \%)$.

Для селективної декомпресії системи ВВ спленоренальний анастомоз сформований у 67 (68,4\%) хворих, у 31 для їі парціальної декомпресії накладали портокавальні анастомози діаметром 7 - 10 мм з інтерпозиційною вставкою або бік у бік.

Основним показанням до накладання дистального спленоренального анастомозу вважали рецидивну кровотечу з варикозно-змінених вен стравоходу і шлунка та неефективність іï ендоскопічного припинення. Протипоказаннями до цього оперативного втручання вважали тромбоз селезінкової вени, наявність відомостей в анамнезі про приступи гострого панкреатиту, набряково-асцитичний синдром (що коригували діуретичними засобами або резистентний до сечогінної терапіі), а також клінічні ознаки печінкової енцефалопатії.

Показаннями до парціальної декомпресії системи ВВ вважали рецидивну кровотечу 3 варикознозмінених вен стравоходу і шлунка за безуспішності ендоскопічного лікування, неможливість формування дистального спленоренального анастомозу, варикозне ураження вен стравоходу IV ступеня на тлі вираженого та стійкого асцитичного синдрому (в тому числі до сечогінної терапії та за відсутності ознак стенозу інтрапечінкової частини нижньої порожнистої вени). Наявність клінічних ознак печінкової енцефалопатії також вважали протипоказанням до оперативного втручання.

Тривалість спостереження безпосередньо після ПКШ 3 - 6 міс, у віддаленому періоді $-4-5$ років.

\section{РЕЗУЛЬТАТИ \\ ТА ÏХ ОБГОВОРЕННЯ}

Варикозне ураження вен стравоходу відзначали в усіх хворих, в тому числі II ступеня - у 5 (5,1\%), III ступеня - у 68 (69,4\%), IV ступеня - у $25(25,5 \%)$.

У 84 (85,7\%) хворих показаннями до виконання ПКШ у плановому порядку були відомості про стравохідно-шлункову кровотечу в анамне3і. Деякі (62) пацієнти повідомляли про неодноразову кровотечу, в тому числі після ендоскопічного видалення варикозно-змінених вен. У 14 (14,3\%) хворих ПКШ виконане з профілактичною метою. Показаннями до виконання різних типів ПКШ у цих пацієнтів були рецидивуючі варикозні зміни вен стравоходу III - IV ступеня, наявність стійкого до лікування асциту в поєднанні з варикозними змінами вен стравоходу (для визначення доцільності виконання хірургічного втручання попередньо визначали портокавальний градієнт тиску, втручання виконували за його абсолютного значення понад 10 мм рт. ст.).

У 57 (58,2\%) пацієнтів для декомпресії ВВ здійснене селективне розвантаження гастроезофагеального венозного басейну шляхом накладання дистального спленоренального анастомозу. За технічної неможливості його виконання, а також за наявності супутнього вираженого асцитичного синдрому у 38 (38,8\%) пацієнтів здійснювали часткове шунтування системи ВВ, використовуючи різні конструкції анастомозів малого діаметра, як правило, формували мезентерикокавальний Н-анастомоз. У 3 хворих 3 приводу стійкого до сечогінних засобів асциту, поєднаного з варикозним ураженням вен стравоходу II ступеня, встановлений черезяремний внутрішньопечінковий портосистемний шунт.

Після операції тромбоз мезентерикокавального Н-анастомозу виник у 5 пацієнтів, тромбозу інших видів портокавальних шунтів не було. Стравохідно-шлункова кровотеча у строки до 3 міс після операції виникла в 11 хворих, у 8 - іiі джерелом були варикозно-змінені вени, причому, за даними контрольної езофагогастрофіброскопії, виявлене поступове зменшення ступеня варикозного ураження вен стравоходу. Спостерігали зменшення напруженості і звивистості варикозних вузлів, спадіння венозних стовбурів при інсуфляції повітря у просвіт стравоходу.

Після операції спостерігали переважно варикозну трансформацію вен III ступеня, у 10 пацієнтів - зберігалася варикозна трансформація IV ступеня. При порівняльному аналізі зменшення ступеня варикозного ураження більш виражене після накладання парціального анастомозу, що зумовлене білыш швидким декомпресивним ефектом ПКШ Важливо, що зниження тиску у ВВ сприяло зменшенню вираженості набряково-асцитичного синдрому. Перед виписуванням асцит (помірно або незначно виражений) зберігався у 47 (48\%) пацієнтів, контролювали застосуванням сечогінних засобів.

Клінічні ознаки енцефалопатії до операції реєстрували у 21 хворого. Після ПКШ з формуванням дистального спленоренального анастомозу неврологічні розлади діагностовані у 5 (5,1\%) хворих, після часткового шунтування у різних варіантах - в 11 (11,2\%). Клінічно ознаки енцефалопатії відповідали I - II ступеню тяжкості, вони були минущими, усунені шляхом призначення дієти з обмеженим споживанням тваринного білка та фармакологічних засобів.

У строки 4 - 5 років обстежені 44 (44,9\%) пацієнти, яким здійснене ПКШ, з них дистальний і спленоренальний анастомози накладені у 29 , різні варіанти парціального шунтування застосовані у 15. Рецидивів стравохідно-шлункової кровотечі не було. Також не виявляли тромбоз судинних з'єднань. У 3 пацієнтів діагностоване порушення функціонування портокавального анастомозу - стеноз інтерпозиційної вставки мезентерикокавального $\mathrm{H}$-анастомозу, що проявлялося прогресуванням варикозного ураження вен стравоходу та асциту.

Всі пацієнти живі.

Таким чином, селективне і парціальне ПКШ з метою корекції портальної гіпертензії у пацієнтів при ЦП є ефективним способом лікування основного захворювання, гарантує попередження стравохідношлункової кровотечі у віддаленому періоді, забезпечує виживання хворих за компенсованої або субкомпенсованої функції печінки. 


\section{ЛITEPATYPA/REFERENCES}

1. Rahmanova AG. Hronicheskie virusnye gepatity i cirroz pecheni. SPb.:SpecLit, 2006. 413 s. [In Russian].

2. Chesnokov EV, Kashuba EA. Hronicheskie gepatity i cirrozy pecheni virusnoj jetiologii. Tjumen, 2000. 286 s. [In Russian].

3. Blaker H, Theuer D, Otto HF. Pathology of liver cirrhosis and portal hypertension. Radiolog. 2001;41:833-9.

4. Orloff MJ, Hye RJ, Wheeler HO, et al. Randomized trials of endoscopic therapy and transjugular intrahepatic portosystemic shunt versus portocaval shunt for emergency and elective treatment of bleeding gastric varices in cirrhosis. Surgery. 2015;157(6):1028-45.

5. Garbuzenko DV. Current approaches to the management of patients with liver cirrhosis who have acute esophageal variceal bleeding. Curr Med Res Opin. 2016;32(3):467-75.
6. Orloff MJ. Fifty-three years' experience with randomized clinical trials of emergency portocaval shunt for bleeding esophageal varices in cirrhosis: 1958-2011. JAMA Surg. 2014;149(2):155-69.

7. Zhao S, Lv T, Gong G, et al. Outcome of laparoscopic splenectomy with sandwich treatment including pericardial devascularization and limited portocaval shunt for portal hypertension due to liver cirrhosis. J Laparoendosc Adv Surg Tech A. 2013;23(1):43-7.

8. Reddy SS, Civan JM. From child-pugh to model for end-stage liver disease: deciding who needs a liver transplant. Med Clin North Am. 2016;100(3):449-64. 